\title{
Targeting clams: insights into the invasive potential and current and future distribution of Asian clams
}

\author{
PAOLA REYNA*1,2, JAVIER NORI ${ }^{1,2,3}$, MARÍA L. BALLESTEROS ${ }^{1,2}$, ANDREA C. HUED ${ }^{1,2}$ \\ AND MARCOS TATIÁN ${ }^{1,2}$ \\ ${ }^{1}$ Universidad Nacional de Córdoba, Facultad de Ciencias Exactas, Físicas y Naturales Departamento de Diversidad Biológica y Ecología, Córdoba, \\ Argentina, ${ }^{2}$ Instituto de Diversidad y Ecología Animal (IDEA) CONICET. Av. Vélez Sarsfield 299, CP5000, Córdoba, Argentina and ${ }^{3}$ Centro de \\ Zoología Aplicada, Facultad de Ciencias Exactas, Físicas y Naturales, Universidad Nacional de Córdoba, Rondeau 798, (5000A) Córdoba, \\ Argentina
}

Date submitted: 10 July 2017; Date accepted: 6 March 2018

\section{SUMMARY}

Bivalves are among the main groups of invasive freshwater species, with the Asian clam genus Corbicula in particular being widely distributed. While global studies have focused on Corbicula fluminea (Müller, 1774), the invasive potential of Corbicula largillierti (Philippi, 1844) and Corbicula fluminalis (Müller, 1774) is still unknown. The spread of invasive species may be intensified by climate change. We estimated and compared environmentally suitable areas for these species under hypothetical climate scenarios, generating global maps of invasion risk. We found large climatically suitable areas for C. largillierti and $C$. fluminalis (under species distribution models) and that their invasive potential is currently underestimated. The analysis revealed many areas in which changing climate may favour the invasion of Corbicula spp.

Keymords: Corbicula largillierti, Corbicula fluminalis, Corbicula fluminea, invasive bivalves, species distribution model, areas of risk

\section{INTRODUCTION}

There has been increasing interest in the study of invasive species due to their strong impact on communities and ecosystems (Vilà et al. 2010). Freshwater ecosystems are particularly vulnerable to this threat: once a species has been introduced, it can spread using different vectors that facilitate passive dispersion among water bodies (Lucy et al. 2012). In particular, invasive bivalves are among the main groups of freshwater invaders with proven direct and indirect impacts on ecosystems, negatively affecting the native species and the biodiversity of invaded habitats (Sousa et al. 2014).

The negative effects of invasive species may be intensified by climate change, producing a positive feedback loop (Pyke et al. 2008). It has been predicted that climate change will

\footnotetext{
*Correspondence: Paola Reyna Email: reynasandrip@gmail.com Supplementary material can be found online at http://dx.doi.org/ $10.1017 / \mathrm{S} 0376892918000139$
}

intensify during this century, accelerating global warming and changing precipitation patterns (IPCC 2014). This will affect aquatic systems by warming water temperatures, altering stream flow patterns and changing water chemistry characteristics (Poff et al. 2002). These changes are expected to produce profound effects on the distribution range and phenology of many species, altering community composition and aquatic ecosystem processes (Hellmann et al. 2008). Thus, climate change will force native species either to rapidly shift their distributional range or adapt to altered conditions (Williams et al. 2007). Given the particular life history characteristics of invasive species (including high fecundity, fast growth and early maturity), they can adapt faster to the new climate conditions than native species and potentially cause fundamental change to ecosystem structure (McMahon 2002).

One of the most problematic bivalve invasions is of the genus Corbicula (Mühlfeld, 1811). These clams may change the ecological condition of freshwater ecosystems, as they are able to alter biochemical cycles and food webs and to compete with native species (Sousa et al. 2008a, 2008b; Azevêdo et al. 2016). Additionally, their invasions have been associated with economic losses, since Corbicula can foul and obstruct filters and turbines, thus damaging cooling systems and affecting water reservoirs, power stations and water treatment plants, among others (Darrigran 2002; Rosa et al. 2011). The native distribution of the genus Corbicula covers areas of Asia, Europe, Africa and Australia (Lee et al. 2005; Sousa et al. 2008a). In the last century, natural and anthropogenic mechanisms have successfully dispersed the genus to many other areas (Sousa et al. 2007). Three species of the genus have become invasive beyond their native range. Corbicula fluminea is the most extended and problematic invasive species of the genus (Gama et al. 2016), and now is found in North, Central and South America (Karatayev et al. 2007). Gama et al. (2016, 2017) suggested that C. fluminea could still further extend its range. Corbicula largillierti has also been recorded as an alien species, with established populations in South and North America (Reyna et al. 2013; Tiemann 2014), while Corbicula fluminalis has been recorded as invasive in Europe and some countries of South America (Korniushin 2004; Martins et al. 2006). Despite these reports, the invasive potential of the latter two species is unknown and ignored. 
One means of defining areas potentially vulnerable to invasion is to utilize correlative models to map regions that fall within abiotic tolerances of a given invasive species (see Peterson et al. 2011). It is then possible to modify those models to reflect hypothetical future climate conditions (e.g. Nori et al. 2011; Guisan et al. 2014). To define the climatic niche and the invasive potential of the genus Corbicula under current and possible future climate scenarios, we estimated and compared their climate niches and potential global distributions and finally assessed the potential effects of climate change on their distributions. Our main goal is to provide useful information to guide conservation policies regarding the management of these problematic species in freshwater ecosystems.

\section{MATERIAL AND METHODS}

Occurrence data of the native and invasive ranges for the three species were obtained from the Global Biodiversity Information Facility (GBIF.org 2017). To improve records, we obtained additional data from bibliographical reviews (Supplementary Appendix S1; available online). For South America, where the databases and literature are sparse, we also obtained records from the collections of the Museo de Ciencias Naturales de La Plata (MLP) and the Museo Argentino de Ciencias Naturales Bernardino Rivadavia (MACN). Records with questionable taxonomy at the species level were excluded. To reduce the effect of spatial autocorrelation and to avoid over-represented areas (Beaumont et al. 2009), we removed duplicate records. We cleaned the database using the SpThin package of R (R Development Core Team 2011; AielloLammens et al. 2015), leaving a single 40-km radius record. Our final database contained 79 records of $C$. largillierti, 85 records of C. fluminalis and 458 records of $C$. fluminea (see Supplementary Appendix S2 for details).

Environmental data for current and future scenarios were downloaded from the WorldClim database (Hijmans et al. 2005). Initially, we considered the 19 available bioclimatic variables (annual mean temperature, mean diurnal, isothermality, temperature seasonality, maximum temperature of warmest month, minimum temperature of coldest month, temperature annual range, mean temperature of wettest quarter, mean temperature of driest quarter, mean temperature of warmest quarter, mean temperature of coldest quarter, annual precipitation, precipitation of wettest month, precipitation of driest month, precipitation seasonality, precipitation of wettest quarter, precipitation of driest quarter, precipitation of warmest quarter, precipitation of coldest quarter), plus altitude with a spatial resolution of 2.5 arc-minutes $(c .5 \mathrm{~km})$. Variables were assigned to baseline conditions corresponding to the average conditions of the time period 1950-2000 (Hijmans et al. 2005). To avoid collinearity among bioclimatic variables, we calculated the Pearson correlation coefficient for each pair of variables. For the modelling procedure, we included only the following lowcorrelated variables $(r<0.75)$ : mean diurnal range, minimum temperature of the coldest month, maximum temperature of the warmest month, precipitation of the wettest quarter, precipitation of the driest quarter and altitude.

To establish suitable areas for present conditions and to study potential changes linked with climate change, we generated species distribution models (SDMs). First, SDMs were calibrated and projected for current climate conditions. Then, these SDMs were projected for the same variables, but considering different future hypothetical climate scenarios. For future climate variables, we considered an intermediate representative concentration pathway (RCP) for the year 2050 $(\mathrm{RCP}=4.5)$. Due to the large uncertainty among different global circulation models (GCMs) in species range projections (Diniz-Filho et al. 2009) and in order to cover the wide variability among them, four different GCMs were used: INMCM4, MIROC5, IPSL-CM5A-LR and CCSM4. The future scenarios were compiled using the Intergovernmental Panel on Climate Change's (IPCC) Fifth Assessment Report (www.ipcc.ch/report/ar5/).

Since alternative SDM algorithms have different levels of accuracy under different circumstances and there is no single 'best' method, multiple algorithms were combined into ensembles (Araújo \& New 2007). We built the ensembles based on four different algorithms, with different mathematical complexities (Rangel \& Loyola 2012): generalized linear models, generalized additive models, generalized boosting methods and random forests. All algorithms were implemented using default settings in the biomod2 package (Thuiller et al. 2009) of R (R Development Core Team 2011). We generated 200 projections for each species $(4$ algorithms $\times 5$ climate scenarios $\times 10$ repetitions). Final ensembles for each climate scenario (current and four GCMs) corresponded to a weighted average of those projections with area under the receiver operating characteristic curve (AUC) values higher than 0.8 and true skill statistic (TSS) values higher than 0.6 (see description of evaluation parameters below). To generate a consensus ensemble for future predictions, we calculated the average raster of the ensembles of all GCMs in ArcGIS 10 (ESRI 2010). To analyse the effect of climate change on suitability patterns of both species, we calculated the difference between current and final ensembles using the 'Raster Calculator' tool in ArcGIS 10 (ESRI 2010).

Environmental conditions within the distribution range of invasive species provide essential information for the implementation of SDMs, and SDMs exclusively calibrated with data from the native range are prone to misrepresent potential distributions of species (Broennimann et al. 2007; Jiménez-Valverde \& Lobo 2007; Beaumont et al. 2009). Therefore, our models were calibrated including records from native and non-native ranges worldwide. Additionally, calibration areas have important implications in model calibration and evaluation (Lobo et al. 2008; Barve et al. 2011) and must be carefully thought out for each study. In these particular cases, given the ability of the species to disperse throughout the world by human transport, pseudoabsences were randomly generated worldwide. We used $70 \%$ 
Table 1 Corbicula spp. evaluation statistics and levels of variable importance $($ mean $\pm \mathrm{SD})$. TSS $=$ true skill statistic; $\mathrm{AUC}=$ area under the receiver operating characteristic curve; ALT = altitude; $\mathrm{MDR}=$ mean diurnal range; $\mathrm{MTW}=$ maximum temperature of warmest month; MTC $=$ minimum temperature of coldest month; $\mathrm{PWQ}=$ precipitation of wettest quarter; $\mathrm{PDQ}=$ precipitation of driest quarter.

\begin{tabular}{llll}
\hline \hline & $\begin{array}{l}\text { Corbicula } \\
\text { largillierti }\end{array}$ & $\begin{array}{l}\text { Corbicula } \\
\text { fluminalis }\end{array}$ & $\begin{array}{l}\text { Corbicula } \\
\text { fluminea }\end{array}$ \\
\hline TSS & $0.82 \pm 0.07$ & $0.81 \pm 0.05$ & $0.74 \pm 0.04$ \\
AUC & $0.94 \pm 0.04$ & $0.95 \pm 0.03$ & $0.93 \pm 0.02$ \\
ALT & $0.07 \pm 0.08$ & $0.11 \pm 0.10$ & $0.17 \pm 0.04$ \\
MDR & $0.12 \pm 0.17$ & $0.16 \pm 0.21$ & $0.06 \pm 0.02$ \\
MTW & $0.28 \pm 0.23$ & $0.12 \pm 0.12$ & $0.14 \pm 0.07$ \\
MTC & $0.34 \pm 0.24$ & $0.37 \pm 0.12$ & $0.46 \pm 0.08$ \\
PWQ & $0.18 \pm 0.13$ & $0.19 \pm 0.14$ & $0.03 \pm 0.02$ \\
PDQ & $0.09 \pm 0.11$ & $0.22 \pm 0.22$ & $0.19 \pm 0.06$ \\
\hline \hline
\end{tabular}

of occurrences to calibrate and the remaining 30\% were used to evaluate each model (Guisan \& Thuiller 2005).

For model evaluation, we implemented the TSS (Allouche et al. 2006) and the AUC (Fielding \& Bell 1997). In addition, biomod 2 allowed us to evaluate the importance of the variables (from 0 (poor) to 1 (very important)) by randomizing one variable at a time and calculating the correlation between the randomized and the true model (Thuiller 2003).

Finally, in order to explore and compare the climate requirements of each species, we estimated the overlap between their climate niches, specifically calculating Schoener's D statistic (Schoener 1968). From these overlaps, a similarity test was performed (Warren et al. 2008). This test shows whether species niches are more similar (or dissimilar) than expected at random (Warren et al. 2008). To carry out these tests, we implemented the PCA-env approach proposed by Broennimann et al. (2012) in the Escopat package in $\mathrm{R}$ (Di Cola et al. 2017), with the five climate variables selected to model and 100 replicates to infer the statistical significance.

\section{RESULTS}

Projections for the three species performed well, with overall mean AUCs of $0.94,0.95$ and 0.93 and mean TSSs of 0.82 , 0.81 and 0.74 for C. largillierti, C. fluminalis and C. fluminea, respectively (Table 1). Although the minimum temperature of the coldest month was the most important predictor for all species, other predictors differed in importance among species (Table 1). Variation in the distributions of the three species under different minimum and maximum temperature ranges, as well as different altitudes worldwide, is given in Supplementary Appendix S3.

For current conditions, the SDM projections showed a high concordance with geographic records of the species. Additionally, we detected new suitability areas where the species has not yet invaded. For $C$. largillierti, these include south-eastern North America, the whole of Central America, central and southern Europe, southern Africa and eastern Australia. Other areas in northern and southwestern New Zealand and southern Asia were also detected as suitable for this species (Fig. 1(a)). For C. fluminalis, large suitable areas were detected in Europe, south-western Asia, southern Australia and south-eastern South America (Fig. 1(b)). Finally, highly suitable areas for C. Aluminea were located in New Zealand, south-eastern Australia and Europe, a small zone in northern and southern Africa, Madagascar, south and south-eastern South America and central and south Asia (Fig. 1(c)).

While most areas would remain relatively stable for the three species, future projections revealed potential areas of significant changes in suitable climate conditions. These projections showed expansion areas for C. largillierti (i.e. areas with high suitability values only in future predictions) located in southeast North America, southern and central South America, central and northern Europe, central and eastern Asia, southern Africa, south-eastern Australia and central Madagascar (Fig. 2(a)). C. fluminalis showed increasing areas in north-eastern North America, South America, Australia, north-eastern Europe, western Asia and northern Africa (Fig. 2(b)). C. fluminea showed increases in climate suitability in Central America and in a band along North America, toward central and north-eastern Europe, southern South America as well as central and eastern Asia (Fig. 2(c)). On the other hand, 'retraction' areas (i.e. areas with high suitability values only with current predictions, not in the future) for C. largillierti were mainly located in central and northern South America, southern North America, southern Africa, north-eastern and southern Australia, Central America and in central and east Asia (Fig. 2(a)). For C. fluminalis, these areas were southern South America, small areas of south-eastern Asia, North America, Australia and in some parts of Europe (Fig. 2(b)). For C. fluminea, they were located in southern and north-western South America, northern Central America and southern North America. Other 'retraction' areas for the same species were identified in an area corresponding to Europe and south-eastern Asia, Australia and northern and southern Africa (Fig. 2(c)).

The niche overlap results showed values of 0.17 between C. largillierti and C. fluminalis; of 0.42 between C. largillierti and $C$. fluminea; and of 0.46 between $C$. fluminalis and $C$. fluminea. The equivalency test showed that the three niches were not equivalent. The similarity test showed the niches of C. largillierti and C. fluminea and of $C$. fluminalis and $C$. fluminea to be more similar than was expected at random $(p<$ 0.05 ; Fig. 3).

\section{DISCUSSION}

Our assessment for the first time of the invasive potential of $C$. largillierti and C. Aluminalis also provided additional evidence of the great invasive potential of $C$. fluminea. Despite the narrower global (i.e. native plus invasive) distribution of $C$. 
Figure 1 Maps of global invasion risk of (a) Corbicula largillierti, (b) Corbicula fluminalis and (c) Corbicula fluminea.

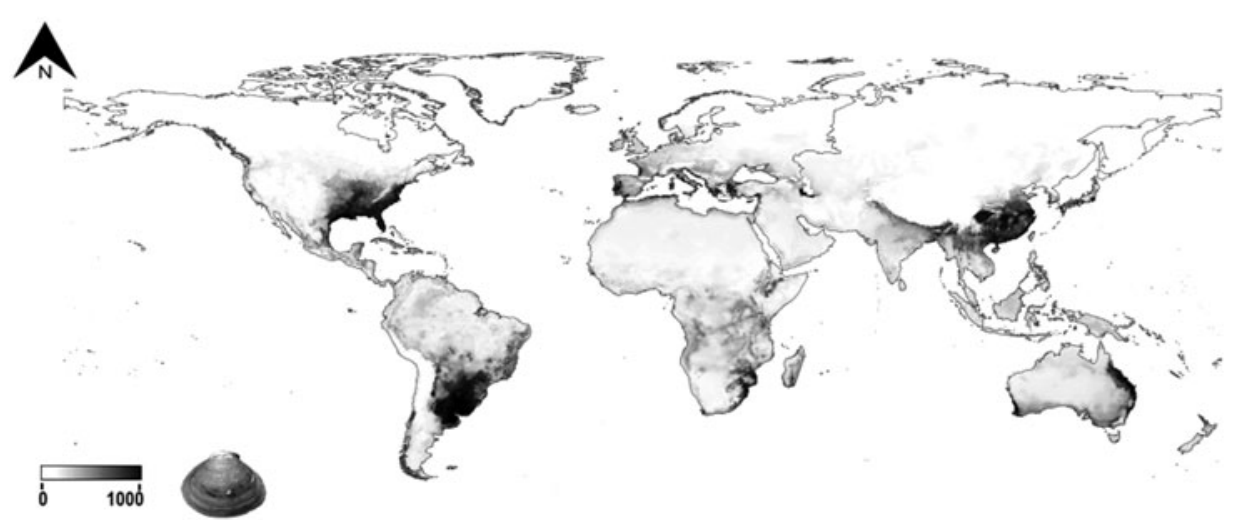

(a)
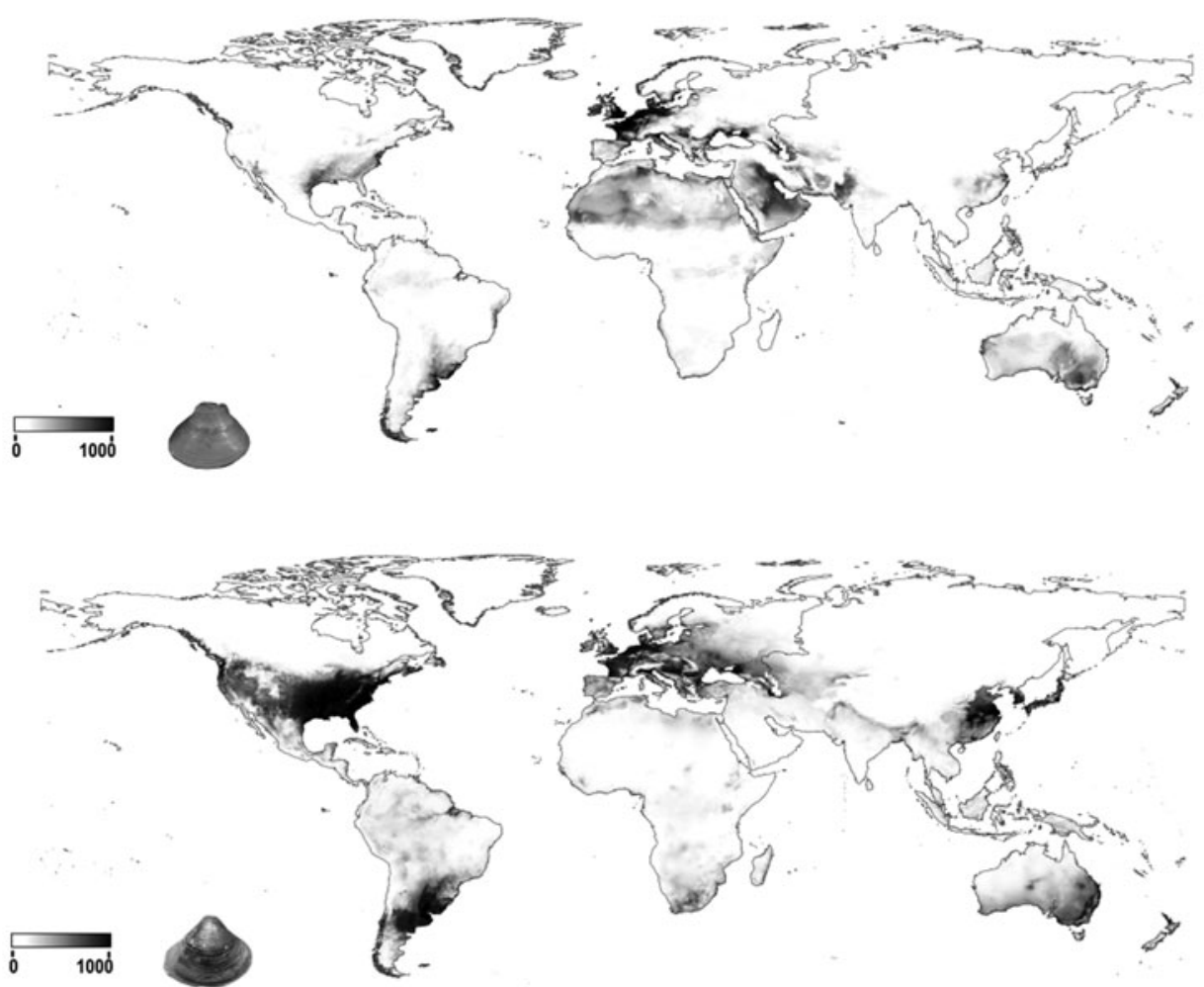

largillierti and C. Aluminalis compared to C. Aluminea, their invasive potential should not be neglected. Both species share close biological characteristics with $C$. fluminea, such as a high fertility rate, short lifespan and fast growth, characteristics that give the latter species its high invasive aptitude (Ituarte 1994; Martins et al. 2006). In the light of our models, we pinpoint a potential shift in distribution as a consequence of future changes in climate.

\section{Current distribution}

At a global scale, climatic environmental limits can accurately predict the areas prone to colonization by freshwater invaders (Karatayev et al. 2007). This approach has been recently validated for C. Aluminea (McDowell et al. 2014; Crespo et al. 2015; Gama et al. 2016). Our models predicted suitable conditions and zones prone to invasion of Corbicula spp. and indicated areas of invasion where $C$. largillierti and $C$. fuminalis have not yet been reported.

In particular, we point out wide areas in which the potential distributions of the three invasive species overlap, highlighting areas with high suitability for them, such as central and southern South America, southern North America, southeastern Asia, south-eastern Australia and Europe. A sympatric distribution of these species is very likely in those areas. This phenomenon was reported in areas of South America where they coexist (Callil \& Mansur 2002; Martins et al. 2004). C. fluminea and C. Aluminalis are also sympatric in Europe (Ciutti \& Cappelletti 2009; Marescaux et al. 2010). In areas where the presence of more than one Corbicula species is possible, interaction between them could magnify the negative effect on native species and ecosystems (Jackson 2015). 
Figure 2 Maps of shifts of future distributions of Corbicula spp. showing differences between current and future scenarios. Colour scale indicates expansion (black), stable distribution (grey) and retraction (white). (a) Corbicula largillierti, (b) Corbicula fluminalis and (c) Corbicula fluminea.
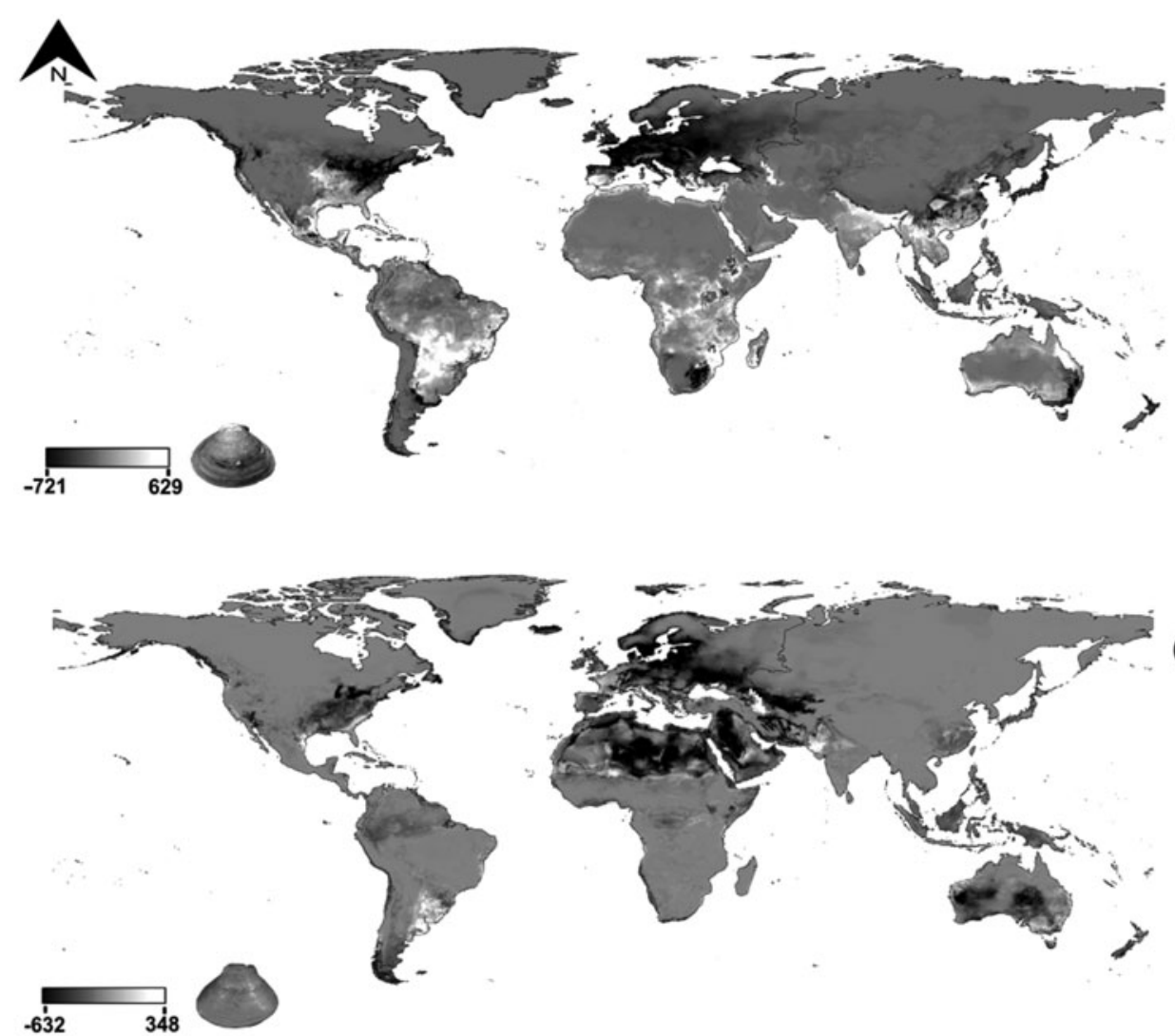

(b)

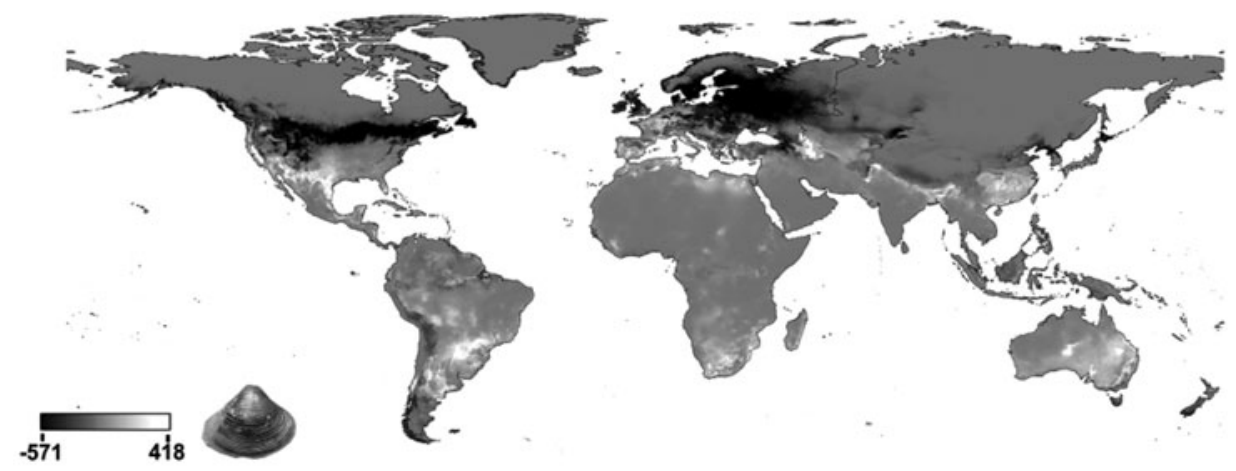

(c)
Figure 3 PCA-env niche overlap between Corbicula spp. (a) Corbicula largillierti and Corbicula fluminea, (b) C. fluminea and Corbicula fluminalis and (c) C. largillierti and C. fluminalis. The solid and the dashed lines correspond to $100 \%$ and $50 \%$, respectively, of the available environment for each range of Corbicula spp. considered in the analysis.

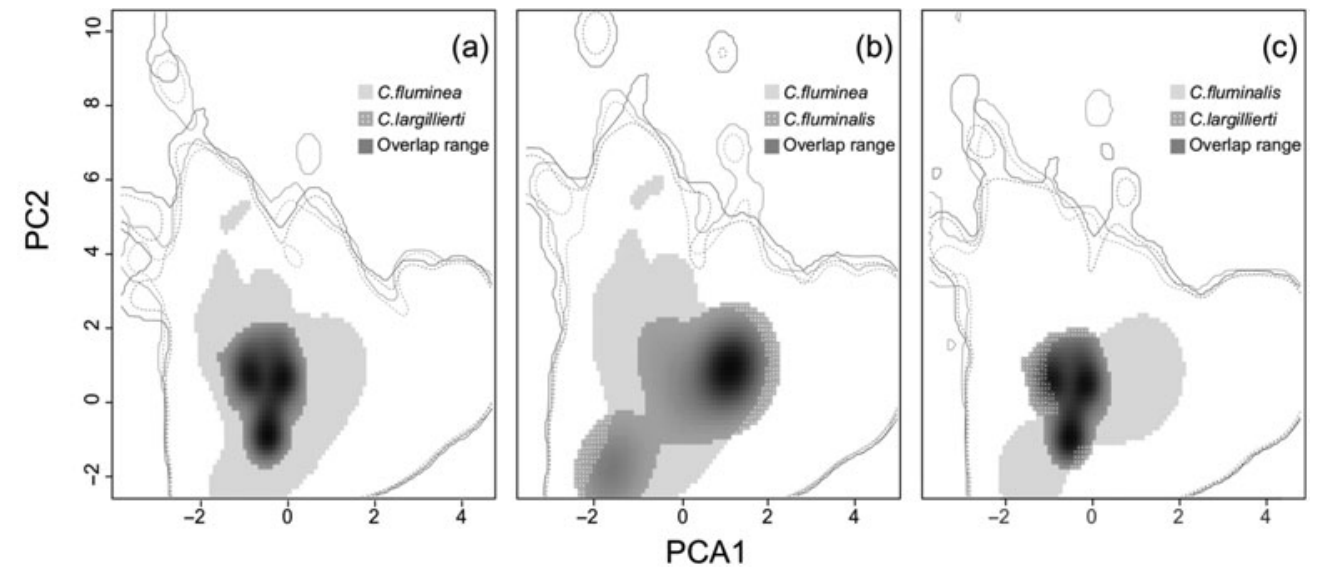


The current relatively narrow distribution of $C$. largillierti and $C$. fluminalis could be explained by different hypotheses: (i) misidentification: even assuming the hypothesis of the existence of lineages from a specific complex, instead of truly species (Pigneur et al. 2011), differences between morphotypes really exist (Mansur \& Pereira 2006; Martins et al. 2006; Reyna et al. 2013). The presence of C. fluminea could be overestimated compared to its congeners. The dispersion and invasion success of $C$. fluminea are well known even by non-specialists, and the presence, for example, of C. largillierti is frequently ignored. (ii) Different capacity for spreading and colonization: since our study highlights large climatically suitable areas for both species, different biological factors, such as a low tolerance to high salt concentrations, could prevent their establishment. It is thus important to note that only $C$. fluminea is present in brackish zones (Sousa et al. 2006) and is therefore easily transported in ballast water. (iii) Competition: although C. largillierti and C. fluminea may be sympatric, it seems that $C$. largillierti is a less effective competitor than C. fluminea. In the Rio de la Plata Basin (where the former species was recorded before than the latter one), the density of $C$. fluminea has increased over that of C. largillierti. Different kinds of interspecific competition, such as space interference, food exploitation or interference from the adults to larval settlement, can occur (Darrigran 1991). This competition may act to filter or force a given species to shift their distribution. (iv) Time of dispersion: C. fluminea was the first species of the genus to spread out of its native range during the first half of the 20th century (Araujo et al. 1993), while C. largillierti and C. fluminalis spread later, at the end of the 1960s and 1980s (Haesloop 1922; Ituarte 1981).

Our projection model for C. fluminea in current climate conditions is quite similar to that recently proposed by Gama et al. (2016, 2017). Central and western South America are detected as risk areas for invasion of $C$. fluminea, but the species has not yet been reported there. It is suspected that C. Aluminea is already invading most of this area (Darrigran 2002), and the gap in the records is probably due to the lack of studies for the species. There are other areas with risk of invasion where the species has not been detected yet, such as New Zealand, a portion of southern Africa, Madagascar and central Asia. Most of south-eastern Australia is highly suitable for the species. Some authors have recently recorded that central and south-eastern Australia are part of the native range of C. fluminea (e.g. Karatayev et al. 2007).

The comparison among climate niches of the species revealed a partial overlap among them, which suggests that some characteristics of the ancestral niche are conserved. Wiens et al. (2010) state that niches of sister species tend to be somewhat conserved, but rarely identical. Corbicula spp. are distributed in some areas within the same climate range, and hence it is expected that their niches will partially overlap. This is consistent with the potential distribution obtained by SMDs. As the climate niche of $C$. largillierti and C. fuminalis is similar to that of $C$. fluminea, they may have a higher invasive potential than previously thought, in view of the invasiveness of the latter species.

\section{Effect of climate change on future distribution ranges}

It is known that climate change benefits the spread of some freshwater invasive species, particularly in terms of expanding their distribution range into regions where they were previously not able to survive and reproduce (Bellard et al. 2013). Although our results suggest that most of the suitable areas for C. largillierti, C. fluminalis and C. fluminea will remain stable, we detected wide zones of expansion of climatically suitable areas in the future, particularly in North America and Europe. For C. fluminea, our results are consistent with those of previous authors (McDowell et al. 2014; Gama et al. 2017). In addition, the present results suggest zones of retraction of suitable conditions in different parts of the world, such as Australia and southern North America for C. Aluminea and C. Aluminalis, as well as South America for C. largillierti and C. fluminalis. These areas will probably be stressful for the species in the near future due to changes in a combination of variables, such as drought and high temperatures (McDowell et al. 2017). Given the potential reduced competitiveness of the species in these areas (Bellard et al. 2013), they could be important sites to focus on for prevention and/or eradication activities.

Gallardo and Aldridge (2013) suggested that an increase in minimum winter temperature would allow the northward expansion of invasive species due to winter warming. Weitere et al. (2009) demonstrated that an increase in temperature in winter had a positive effect on the growth rate and reproduction of $C$. fluminea. Our results showed the minimum temperature of the coldest month was the most important variable in the models for the three species. Considering that climate change will have an effect on minimum temperatures mainly in cooler climates (IPCC 2014), it is very likely that this effect may produce a change in the worldwide distribution of Corbicula spp. On the other hand, climate change could have a negative effect on native species (Sorte et al. 2013), making them less competitive or leaving empty niches that could favour the invasion of Corbicula spp.

There is increasing evidence that invasive species may benefit from climate change, with strong ecological and economic implications (Kernan 2015). Thus, prevention policies are among the best and cheapest strategies to control biological invasions (Pyke et al. 2008; Gallardo \& Aldridge 2013). We highly recommend the control of human activities that are main dispersal vectors. Prevention could focus on fishers that sometimes use Corbicula spp. as bait, as well as the control of sports boats that move from one basin to another and the ballast water of ships that arrive in ports. Environmental education is another way to prevent or to detect invasive species early. Our results indicate that $C$. largillierti and, to a lesser extent, C. fluminalis have great potential to invade new areas. It is imperative to generate additional (such as physiological or demographic) information for management 
policies to control potential invasion pathways for these species. Finally, we strongly encourage the consideration of our findings in future eradication and control programmes.

\section{ACKNOWLEDGEMENTS}

The authors would like to thank Dr Darrigran and Dr Tablado, who kindly allowed access to the MLP and MACN, respectively; and also Dr Perez, Dr Graf, Dr Galli and Dr Beasley for providing the records data. We are also grateful to Dr Torres, Dr Rojas-Soto and Dr Di Cola for helping with the methodology and to T. Maggioni and G. Alurralde for improving the manuscript with their comments and suggestions. This work is part of a doctoral thesis by P.R. at the Universidad Nacional de Córdoba (UNC).

\section{FINANCIAL SUPPORT}

P.R. acknowledges financial support from CONICET, Argentina (doctoral fellowship). The study was supported by SECyT-UNC 30720150100406CB.

\section{CONFLICT OF INTEREST}

None.

\section{ETHICAL STANDARDS}

None.

\section{Supplementary material}

To view supplementary material for this article, please visit https://doi.org/10.1017/S0376892918000139

\section{References}

Aiello-Lammens, M.E., Boria, R.A., Radosavljevic, A., Vilela, B. \& Anderson, R.P. (2015) spThin: an R package for spatial thinning of species occurrence records for use in ecological niche models. Ecography 38: 541-545.

Allouche, O., Tsoar, A. \& Kadmon, R. (2006) Assessing the accuracy of species distribution models: prevalence, kappa and the true skill statistic (TSS). Fournal of Applied Ecology 43: 1223-1232.

Araújo, M.B. \& New, M. (2007) Ensemble forecasting of species distributions. Trends in Ecology E Evolution 22: 42-47.

Araujo, R., Moreno, D. \& Ramos, M. (1993) The Asiatic clam Corbicula fluminea (Müller, 1774) (Bivalvia: Corbiculidae) in Europe. American Malacological Bulletin 10: 39-49.

Azevêdo, E.D.L., Barbosa, J.E.D.L., Vidigal, T.H.D.A., Marques, J.C., Callisto, M. \& Molozzi, J. (2016) Potential ecological distribution of alien mollusk Corbicula largillierti and its relationship with human disturbance in a semi-arid reservoir. Biota Neotropica 16: e0109.

Barve, N., Barve, V., Jiménez-Valverde, A., Lira-Noriega, A., Maher, S.P., Peterson, A.T., Soberón, J. \& Villalobos, F. (2011) The crucial role of the accessible area in ecological niche modeling and species distribution modeling. Ecological Modelling 222: 18101819.

Beaumont, L.J., Gallagher, R.V., Thuiller, W., Downey, P.O., Leishma, M.R. \& Hughes, L. (2009) Different climatic envelopes among invasive populations may lead to underestimations of current and future biological invasions. Diversity and Distributions 15: 409-420.

Bellard, C., Thuiller, W., Leroy, B., Genovesi, P., Bakkenes, M. \& Courchamp, F. (2013) Will climate change promote future invasions? Global Change Biology 19: 3740-3748.

Broennimann, O., Fitzpatrick, M.C., Pearman, P.B., Petitpierre, B., Pellissier, L., Yoccoz, N.G., Thuiller, W., Fortin, M.J., Randin, C., Zimmermann, N.E., Graham, C.H. \& Guisan, A. (2012) Measuring ecological niche overlap from occurrence and spatial environmental data. Global Ecology and Biogeography 21: 481-497.

Broennimann, O., Treier, U.A., Müller-Schärer, H., Thuiller, W., Peterson, A.T. \& Guisan, A. (2007) Evidence of climatic niche shift during biological invasion. Ecology Letters 10: 701-709.

Callil, C.T. \& Mansur, M.C.D. (2002) Corbiculidae in the Pantanal: history of invasion in southeast and central South America and biometrical data. Amazoniana 17: 153-167.

Ciutti, F. \& Cappelletti, C. (2009) First record of Corbicula fluminalis (Müller, 1774) in Lake Garda (Italy), living in sympatry with Corbicula fluminea (Müller, 1774). Journal of Limnology 68: 162.

Di Cola, V., Broennimann, O., Petitpierre, B., Breiner, F.T., D'Amen, M., Randin, C., Engler, R., Pottier, J., Pio, D., Dubuis, A., Pellissier, L., Mateo, R.G., Hordijk, W., Salamin, N. \& Guisan, A. (2017) ecospat: an R package to support spatial analyses and modeling of species niches and distributions. Ecography 40 : 774-787.

Crespo, D., Dolbeth, M., Leston, S., Sousa, R. \& Pardal, MÂ. (2015) Distribution of Corbicula fluminea (Müller, 1774) in the invaded range: a geographic approach with notes on species traits variability. Biological Invasions 17: 2087-2101.

Darrigran, G. (2002) Potential impact of filter-feeding invaders on temperate inland freshwater environments. Biological Invasions: 145-156.

Darrigran, G. (1991) Competencia entre dos especies de pelecipodos invasores, Corbicula fluminea (Müller, 1774) y C. largillierti (Phillipi, 1844). En el litoral argentino del estuario del Rio de La Plata. Biología Acuática 15: 214-215.

Diniz-Filho, J.A.F., Bini, M.L., Rangel, F.T., Loyola, R.D., Hof, C., Nogués-Bravo, D. \& Araújo, M.B. (2009) Partitioning and mapping uncertainties in ensembles of forecasts of species turnover under climate change. Ecography 32: 897-906.

ESRI (2010) ArcMap GIS, ver. 10. Redlands, CA, USA: Environmental Systems Research Institute.

Fielding, A.H. \& Bell, J.F. (1997) A review of methods for the assessment of prediction errors in conservation presence/ absence models. Environmental Conservation 24: 38-49.

Gallardo, B. \& Aldridge, D.C. (2013) Evaluating the combined threat of climate change and biological invasions on endangered species. Biological Conservation 160: 225-233.

Gama, M., Crespo, D., Dolbeth, M. \& Anastácio, P. (2016) Predicting global habitat suitability for Corbicula fluminea using species distribution models: the importance of different environmental datasets. Ecological Modelling 319: 163-169.

Gama, M., Crespo, D., Dolbeth, M. \& Anastácio, P.M. (2017) Ensemble forecasting of Corbicula fluminea worldwide distribution: projections of the impact of climate change. Aquatic Conservation: Marine and Freshmater Ecosystems 27: 675-684. 
GBIF.org (2017) Global Biodiversity Information Facility. URL www.gbif.org

Guisan, A., Petitpierre, B., Broennimann, O., Daehler, C. \& Kueffer, C. (2014) Unifying niche shift studies: insights from biological invasions. Trends in Ecology E Evolution 29: 260-269.

Guisan, A. \& Thuiller, W. (2005) Predicting species distribution: offering more than simple habitat models. Ecology Letters 8: 9931009 .

Haesloop, U. (1922) Establishment of the Asiatic clam Corbicula cf. fluminalis in the tidal Weser River (N. Germany). Archiv für Hydrobiologie 126: 175-180.

Hellmann, J.J., Byers, J.E., Bierwagen, B.G. \& Dukes, J.S. (2008) Five potential consequences of climate change for invasive species. Conservation Biology 22: 534-543.

Hijmans, R.J., Cameron, S.E., Parra, J.L., Jones, P.G. \& Jarvis, A. (2005) Very high resolution interpolated climate surfaces for global land areas. International fournal of Climatology 25: 19651978.

IPCC (2014) Fifth Assessment Report of the Intergovernmental Panel on Climate Change. URL www.tandfonline.com/doi/ abs $/ 10.4155 / \mathrm{cmt} .13 .80$

Ituarte, C.F. (1981) Primera noticia acerca de la introducción de Pelecípodos Asiáticos en el área Rioplatense. Neotropica 27: 7982.

Ituarte, C.F. (1994) Corbicula and Neocorbicula (Bivalvia: Corbiculidae) in the Paraná, Uruguay, and Rio de La Plata Basins. The Nautilus 7: 129-135.

Jackson, M.C. (2015) Interactions among multiple invasive animals. Ecology 96: 2035-2041.

Jiménez-Valverde, A. \& Lobo, J.M. (2007) Threshold criteria for conversion of probability of species presence to either-or presence-absence. Acta Oecologica 31: 361-369.

Karatayev, A.Y., Padilla, D.K., Minchin, D., Boltovskoy, D. \& Burlakova, L.E. (2007) Changes in global economies and trade: the potential spread of exotic freshwater bivalves. Biological Invasions 9: $161-180$.

Kernan, M. (2015) Climate change and the impact of invasive species on aquatic ecosystems. Aquatic Ecosystem Health $E$ Management 18: 321-333.

Korniushin, A.V. (2004) A revision of some Asian and African freshwater clams assigned to Corbicula fluminalis (Müller, 1774) (Mollusca: Bivalvia: Corbiculidae), with a review of anatomical characters and reproductive features based on museum collections. Hydrobiologia 529: 251-270.

Lee, T., Siripattrawan, S., Ituarte, F. \& Diarmaid, O.F. (2005) Invasion of the clonal clams: Corbicula lineages in the New World. American Malacological Bulletin 20: 113-122.

Lobo, J.M., Jiménez-Valverde, A. \& Real, R. (2008) AUC: a misleading measure of the performance of predictive distribution models. Global Ecology and Biogeography 17: 145-151.

Lucy, F., Karatayev, A. \& Burlakova, L. (2012) Predictions for the spread, population density, and impacts of Corbicula fluminea in Ireland. Aquatic Invasions 7: 465-474.

Mansur, M.C.D. \& Pereira, D. (2006) Bivalves límnicos da bacia do rio dos Sinos, Rio Grande do Sul, Brasil (Bivalvia, Unionoida, Veneroida e Mytiloida). Revista Brasileira de Zoologia 23: 11231147.

Marescaux, J., Pigneur, L.M. \& Van Doninck, K. (2010) New records of Corbicula clams in French rivers. Aquatic Invasions 5: 35-39.

Martins, D.S., Veitenheimer-Mendes, I.L. \& Faccioni-Heuser, M.C. (2006) Aspectos morfológicos e de incubação em três espécies de Corbicula Mühlfeld, no lago Guaíba, Rio Grande do Sul, Brasil (Bivalvia, Corbiculidae). Biota Neotropica 6: 1-11.

Martins, S., Veitenheimer-mendes, I.L. \& Faccioni-heuser, M.C. (2004) Corbicula (Bivalvia, Corbiculidae) em simpatria no Lago Guaíba, Rio Grande do Sul, Brasil. Biociências (Porto Alegre) 12: 129-138.

McDowell, W.G., Benson, A.J. \& Byers, J.E. (2014) Climate controls the distribution of a widespread invasive species: implications for future range expansion. Freshwater Biology 59: 847857.

McDowell, W.G., McDowell, W.H. \& Byers, J.E. (2017) Mass mortality of a dominant invasive species in response to an extreme climate event: implications for ecosystem function. Limnology and Oceanography 62: 177-188.

McMahon, R.F. (2002) Evolutionary and physiological adaptations of aquatic invasive animals: $r$ selection versus resistance. Canadian Journal of Fisheries and Aquatic Sciences 59: 12351244.

Nori, J., Akmentins, M.S., Ghirardi, R., Frutos, N. \& Leynaud, G.C. (2011) American bullfrog invasion in Argentina: where should we take urgent measures? Biodiversity and Conservation 20: 1125 1132.

Peterson, T., Soberón, J., Pearson, R.G., Anderson, R.P., MartínezMeyer, E., Nakamura, M. \& Araújo, M.B. (2011) Ecological Niches and Geographic Distributions (MPB-49). Princeton, NJ, USA: Princeton University Press.

Pigneur, L.M., Marescaux, J., Roland, K., Etoundi, E., Descy, J.P. \& Van Doninck, K. (2011) Phylogeny and androgenesis in the invasive Corbicula clams (Bivalvia, Corbiculidae) in Western Europe. BMC Evolutionary Biology 11: 147.

Poff, N.L., Brinson, M.M. \& Day, J.W. (2002) Aquatic Ecosystems: Effects of Solar Ultraviolet Radiation and Interactions with Other Climatic Change Factors. Arlington, VA, USA: Pew Center on Global Climate Change.

Pyke, C.R., Thomas, R., Porter, R.D., Hellmann, J.J., Dukes, J.S., Lodge, D.M. \& Chavarria, G. (2008) Current practices and future opportunities for policy on climate change and invasive species. Conservation Biology 22: 585-592.

R. Development Core Team (2011) R: A Language and Environment for Statistical Computing. Vienna, Austria: The R Foundation for Statistical Computing.

Rangel, T.F. \& Loyola, R.D. (2012) Labeling ecological niche models. Natureza E Conservação 10: 119-126.

Reyna, P.B., Morán, A.G. \& Tatián, M. (2013) Taxonomy, distribution and population structure of invasive Corbiculidae (Mollusca, Bivalvia) in the Suquía River basin, Córdoba, Argentina. Iheringia, Série Zoologia 103: 77-84.

Rosa, I.C., Pereira, J.L., Gomes, J., Saraiva, P.M., Gonçalves, F. \& Costa, R. (2011) The Asian clam Corbicula fluminea in the European freshwater-dependent industry: a latent threat or a friendly enemy? Ecological Economics 70: 1805-1813.

Schoener, T.W. (1968) The Anolis lizards of Bimini: resource partitioning in a complex fauna. Ecology 49: 704-726.

Sorte, C.JB., Ibáñez, I., Blumenthal, D.M., Molinari, N.A., Miller, L., Grosholz, E.D., Diez, J.M., D’Antonio, C.M., Olden, J.D., Jones, S.J. \& Dukes, J.S. (2013) Poised to prosper? A cross-system comparison of climate change effects on native and non-native species performance. Ecology Letters 16: 261270.

Sousa, R., Antunes, C. \& Guilhermino, L. (2006) Factors influencing the occurrence and distribution of Corbicula fluminea (Müller, 
1774) in the River Lima estuary. Annales de Limnologie International Fournal of Limnology 42: 165-171.

Sousa, R., Antunes, C. \& Guilhermino, L. (2008a) Ecology of the invasive Asian clam Corbicula fluminea (Müller, 1774) in aquatic ecosystems: an overview. Annales de Limnologie - International Fournal of Limnology 44: 85-94.

Sousa, R., Freire, R., Rufino, M., Méndez, J., Gaspar, M., Antunes, C. \& Guilhermino, L. (2007) Genetic and shell morphological variability of the invasive bivalve Corbicula fluminea (Müller, 1774) in two Portuguese estuaries. Estuarine, Coastal and Shelf Science 74: $166-174$.

Sousa, R., Novais, A., Costa, R. \& Strayer, D.L. (2014) Invasive bivalves in fresh waters: impacts from individuals to ecosystems and possible control strategies. Hydrobiologia 735: 233-251.

Sousa, R., Rufino, M., Gaspar, M., Antunes, C. \& Guilhermino, L. (2008b) Abiotic impacts on spatial and temporal distribution of Corbicula fluminea (Müller, 1774) in the River Minho Estuary, Portugal. Aquatic Conservation: Marine and Freshmater Ecosystems 18: $98-110$.

Thuiller, W. (2003) BIOMOD: optimising predictions of species distributions and projecting potential future shift under global change. Global Change Biology 9: 1353-1362.

Thuiller, W., Lafourcade, B., Engler, R. \& Araüjo, M.B. (2009) BIOMOD - a platform for ensemble forecasting of species distributions. Ecography 32: 369-373.
Tiemann, J. (2014) Freshwater Mollusks of the Middle Mississippi River. Illinois Natural History Survey. URL www. ideals.illinois.edu/handle/2142/47061

Vilà, M., Basnou, C., Pyšek, P., Josefsson, M., Genovesi, P., Gollasch, S., Nentwig, W., Olenin, S., Roques, A., Roy, D. \& Hulme, P.E. (2010) How well do we understand the impacts of alien species on ecosystem services? A pan-European, cross-taxa assessment. Frontiers in Ecology and the Environment 8: 135-144.

Warren, D.L., Glor, R.E. \& Turelli, M. (2008) Environmental niche equivalency versus conservatism: quantitative approaches to niche evolution. Evolution 62: 2868-2883.

Weitere, M., Vohmann, A., Schulz, N., Linn, C., Dietrich, D. \& Arndt, H. (2009) Linking environmental warming to the fitness of the invasive clam Corbicula fluminea. Global Change Biology 15: 2838-2851.

Wiens, J.J., Ackerly, D.D., Allen, A.P., Anacker, B.L., Buckley, L.B., Cornell, H.V., Damschen, E.I., Jonathan Davies, T., Grytnes, J.A., Harrison, S.P., Hawkins, B.A., Holt, R.D., McCain, C.M. \& Stephens, P.R. (2010) Niche conservatism as an emerging principle in ecology and conservation biology. Ecology Letters 13: 1310-1324.

Williams, J.W., Jackson, S.T. \& Kutzbach, J.E. (2007) Projected distributions of novel and disappearing climates by 2100 AD. Proceedings of the National Academy of Sciences of the United States of America 104: 5738-5742. 